\title{
Evaluation of a microbiological indicator test for antibiotic detection in ewe and goat milk
}

\author{
R. Comunian, ${ }^{1}$ A. Paba, I. Dupré, E. S. Daga, and M. F. Scintu \\ Dipartimento per la Ricerca nelle Produzioni Animali, AGRIS Sardegna, Loc. Bonassai, I-07040 Olmedo (SS), Italy
}

\section{ABSTRACT}

Antibiotics are widely used for therapeutic and prophylactic purposes in dairy animals. The presence of residual antibiotics in milk could cause potentially serious problems in human health and have technological implication in the manufacturing of dairy products. The aim of this study was to evaluate Delvotest Accelerator (DSM Food Specialties, Delft, the Netherlands), a new system for a fully automated microbial test to detect antibiotic residues in ewe and goat milk. Forty-three samples of raw, whole, refrigerated bulk-tank milk samples ( 22 of ewe milk and 21 of goat milk) were analyzed during the whole lactation period. Four concentrations of 4 antibiotics were diluted in milk: penicillin $\mathrm{G}$ at 1 , 2,3 , and $4 \mu \mathrm{g} / \mathrm{L}$; sulfadiazine at 25, 50, 100, and 200 $\mu \mathrm{g} / \mathrm{L}$; tetracycline at 50,100, 200, and $400 \mu \mathrm{g} / \mathrm{L}$; and gentamicin at $25,50,100$, and $200 \mu \mathrm{g} / \mathrm{L}$. The detection limit of the Delvotest Accelerator was calculated as the range of antibiotic concentrations within which $95 \%$ of positive result lie. The range of detection limit of penicillin $\mathrm{G}$ and sulfadiazine was easily detected by Delvotest Accelerator at or below the European Union maximum residue limits, both for ewe and goat milk samples. In contrast, the system showed a lower ability to detect tetracycline and gentamicin both for ewe and goat milk samples. Very low percentages of false-positive outcomes were obtained. Lactation phase did not seem to be a crucial factor affecting the ability of the Delvotest Accelerator to detect spiked milk samples. A higher detection ability was observed for goat milk samples compared with ewe milk samples. A negative correlation between the percentage of positive milk samples detected and milk fat, protein, and lactose contents was observed for gentamicin only.

Key words: ewe and goat milk, antibiotic, microbial test, Delvotest Accelerator

Received May 26, 2010.

Accepted September 12, 2010.

${ }^{1}$ Corresponding author: rcomunian@agrisricerca.it

\section{INTRODUCTION}

Antibiotics are widely used for therapeutic and prophylactic purposes in human and veterinary medicine. In regard to dairy animals, if the proper withdrawal periods are not observed before milking, milk may be contaminated with residual antibiotics that can cause potentially serious problems to human health, such as allergic or toxic reactions or drug resistance, and technological implications in the manufacture of dairy products (Perreten and Teuber, 1995; Althaus et al., 2003; Molina et al., 2003a; Demoly and Romano, 2005; Beltran et al., 2007).

To avoid risks related to drug residues, maximum residue limits (MRL) have been established by law in many countries for each antimicrobial agent. In the European Union, the MRL (EU-MRL) of veterinary medicinal products in foodstuffs of animal origin are established by the Codex Alimentarius Commission (2009), the Regulation (EC) n. 470/09 (European Union, 2009) repealing the Council Regulation n. 2377/90 (European Union, 1990), and the Commission Regulation (EU) n. 37/2010 (European Union, 2010). In the United States, regulatory levels are called tolerances and are suggested by the US FDA Center for Veterinary Medicine.

Different methods of analysis for the detection of residues of inhibitors in milk have been developed and evaluated (Wang et al., 2006). Among them, microbial methods, generally based on the growth inhibition of Geobacillus stearothermophilus var. calidolactis (Delvotest SP-NT, BR-Test AS-Brilliant, DSM Food Specialties, Delft, the Netherlands; Charm Blue Yellow II Test, Charm Sciences Inc., Lawrence, MA; CMT-Copan milk test, Copan Italia, S.p.A., Brescia, Italy; and Eclipse 50, Zeu-Inmunotec S.L., Zaragoza, Spain), are widely used and are quick, easy to use, and economical. Nevertheless, visual assessment of some of these tests is subjective and they are often difficult to interpret. To overcome these limitations, Althaus et al. (2003) proposed to combine Delvotest SP-NT system with a photometric measurement in an ELISA reader. Moreover, most of the microbial methods have been developed and evaluated for cow milk, and few studies have been carried out so far for ewe and goat milks 
Table 1. List of the antibiotics used for the evaluation tests, the assessed concentrations, and the respective European Union maximum residue limits (EU-MRL)

\begin{tabular}{|c|c|c|c|c|c|c|}
\hline \multirow[b]{2}{*}{ Class and antibiotic } & \multirow{2}{*}{$\begin{array}{l}\text { Product } \\
\text { number }\end{array}$} & \multicolumn{4}{|c|}{ Concentration, $\mu \mathrm{g} / \mathrm{L}$} & \multirow{2}{*}{$\begin{array}{c}\text { EU-MRL } \\
\mu \mathrm{g} / \mathrm{L}\end{array}$} \\
\hline & & 1 & 2 & 3 & 4 & \\
\hline$\beta$-Lactam & & & & & & \\
\hline $\begin{array}{l}\text { Penicillin G potassium salt } \\
\text { Sulphonamide }\end{array}$ & Sigma P7794 & 1 & 2 & 3 & 4 & 4 \\
\hline Sulfadiazine sodium salt & Sigma S6387 & 25 & 50 & 100 & 200 & 100 \\
\hline $\begin{array}{l}\text { Tetracycline } \\
\text { Tetracycline hydrochloride } \\
\text { Aminoglycoside }\end{array}$ & Sigma T3383 & 50 & 100 & 200 & 400 & 100 \\
\hline Gentamicin sulfate & Sigma 48460 & 25 & 50 & 100 & 200 & 100 \\
\hline
\end{tabular}

${ }^{1}$ Sigma Chemical Co., St. Louis, MO.

(Contreras et al., 1997; Althaus et al., 2003; Molina et al., 2003a,b; Montero et al., 2005; Beltran et al., 2007; Sierra et al., 2007, 2009a,b).

Recently, DSM Food Specialties produced a fully automated system, Delvotest Accelerator, that automatically incubates and scans up to four 96-well, multi-test Accelerator plates ( $\mathrm{n}=384$ samples) simultaneously, sending the results directly to a database and performing a quick and easy analysis. Until now, Delvotest Accelerator has been tested only for cow and goat milk (information supplied by the manufacturer). In particular, ewe milk is characterized by elevated concentrations of fat, protein, minerals, and somatic cells and by high seasonal variability of these traits. Several authors report that this may interfere with the response rates of microbiological inhibitor tests (Andrew, 2000; Molina et al., 2003a; Yamaki et al., 2004).

The aim of this work was to evaluate the ability of Delvotest Accelerator to detect 4 antibiotics, belonging to 4 of the most widely used classes in veterinary medicine, in ewe and goat raw, whole milks during the whole lactation period.

\section{MATERIALS AND METHODS}

\section{Milk Samples}

The milk samples were collected in the same period, both for ewe and goat milks. The whole lactation period was divided into 3 phases, each lasting 1 mo: early (phase 1: February 15 to March 15), middle (phase 2: April 1 to May 1), and final (phase 3: June 15 to July 15). A total of 43 samples of raw whole, refrigerated bulk-tank milk, 22 samples from a flock of more than 500 extensively reared Sarda dairy ewes and 21 from a flock of 62 stall-fed crossbreed goats (Sarda, Saanen, and Maltese breeds), were collected from the experimental farm at AGRIS Sardegna Research Agency (Olmedo, SS, Italy). To ensure that the milk collected was free of antibiotics, we adapted the requirements of the guidance on the standardized evaluation of microbial inhibitor tests (IDF, 2003). The animals were in good health status and free of antibiotic treatment for at least 8 wk before milk collection.

\section{Milk Analyses}

Milk samples were analyzed by using MilkoScan 4000 (Foss Electric A/S, Hillerød, Denmark) for their chemical composition (fat, protein, lactose), and for SCC by Fossomatic 5000 (Foss Electric A/S). The level of bacteria in milk samples was determined by SPC (IDF, 1991); pH value was also measured (pH302 Hanna Instruments, Leighton Buzzard, UK).

\section{Antibiotic Evaluation Trials}

A stock solution of each antibiotic was prepared in water. Final solutions in milk were obtained by adding the stock solution to the ewe and goat milk samples in a portion $\leq 1 \%$ of the final milk volume (IDF, 2003). The chosen antibiotics, the assessed concentrations, and the respective EU-MRL are reported in Table 1. For each antibiotic, each trial was performed using 1 milk sample collected on the same day or on the day before the trial, and immediately cooled at $4^{\circ} \mathrm{C}$. Sometimes, different aliquots of the same milk sample were used to test different antibiotics on the same day. During each phase, 4 milk samples of each species collected on different days were spiked with different antibiotics to assess their detectability.

For each trial, at least two 96-well multi-test Accelerator plates were manually filled by using a micropipette, inoculating 15 replicates of each concentration of antibiotic and 36 negative controls (blanks) per plate, according to the scheme reported in Figure 1. For each drug, 12 trials ( 4 trials $\times 3$ lactation phases) were performed using milk samples collected on different days. In particular, for each drug concentration, at least 120 replicates were tested $(15$ replicates $\times 2$ plates $\times 4 \mathrm{~d}$ ). 


\begin{tabular}{|c|c|c|c|c|c|c|c|c|c|c|c|c|}
\hline & 1 & 2 & 3 & 4 & 5 & 6 & 7 & 8 & 9 & 10 & 11 & 12 \\
\hline A & $\mathrm{BL}$ & 4 & 3 & 2 & 1 & BL & BL & 4 & 3 & 2 & 1 & $\overline{B L}$ \\
\hline B & $\mathrm{BL}$ & BL & 4 & 3 & 2 & 1 & BL & $\mathrm{BL}$ & 4 & 3 & 2 & 1 \\
\hline C & $\mathrm{BL}$ & BL & $\mathrm{BL}$ & 4 & 3 & 2 & 1 & $\mathrm{BL}$ & $\mathrm{BL}$ & 4 & 3 & 2 \\
\hline D & 1 & BL & $\mathrm{BL}$ & $\mathrm{BL}$ & 4 & 3 & 2 & 1 & $\mathrm{BL}$ & BL & 4 & 3 \\
\hline E & 2 & 1 & $\mathrm{BL}$ & $\mathrm{BL}$ & BL & 4 & 3 & 2 & 1 & BL & BL & 4 \\
\hline$F$ & 3 & 2 & 1 & $\mathrm{BL}$ & BL & $\mathrm{BL}$ & 4 & 3 & 2 & 1 & $\mathrm{BL}$ & $\mathrm{BL}$ \\
\hline G & 4 & 3 & 2 & 1 & BL & $\mathrm{BL}$ & BL & 4 & 3 & 2 & 1 & $\mathrm{BL}$ \\
\hline H & BL & 4 & 3 & 2 & 1 & BL & BL & $\mathrm{BL}$ & 4 & 3 & 2 & 1 \\
\hline
\end{tabular}

$1,2,3$ and $4=$ concentrations of tested antibiotics

$\mathrm{BL}=$ blank/negative control

Figure 1. Plate inoculation scheme for a 96 -well multi-test.

Moreover, additional trials were performed for tetracycline and gentamicin, inoculating the plates with the same concentrations of the antibiotics in water instead of milk. The Delvotest Accelerator system was operated as detailed in the manufacturer's test kit instructions (V1.0 2007-08-01).

The detection limit of the Delvotest Accelerator was expressed as the 2 concentrations of antibiotic $(>\mu \mathrm{g} / \mathrm{L}$ to $<\mu \mathrm{g} / \mathrm{L}$ ) between which the intersection of the doseresponse curve and the line representing $95 \%$ positive results lies. For each antibiotic, the range of detection limit was calculated for each species and lactation phase.

\section{Statistical Analysis}

To evaluate the association between the species and the detection ability of Delvotest Accelerator, a 2-sided Fisher's exact test was used. The association between lactation phase and detection ability was evaluated by using $\chi^{2}$ test, and when an expected frequency was $<5$ the Fisher's exact test was applied. A significant difference was defined by $P \leq 0.05$. The effect of lactation phase on $\mathrm{pH}$, fat, protein, lactose, SCC, and SPC was evaluated by one-way ANOVA $(P \leq 0.05)$. More- over, the possible correlation between the percentage of spiked milk samples detected and variations in the milk parameters $(\mathrm{pH}$, fat, protein, lactose, SCC, and SPC) was calculated for each antibiotic concentration as Pearson correlation coefficient. Statistical analysis was performed using Minitab statistical package, release 15 (Minitab Inc., State College, PA), and Fisher's exact test performed with SAS (version 8, 1999; SAS Institute Inc., Cary, NC).

\section{RESULTS AND DISCUSSION}

\section{Milk Analyses}

Milk analyses results are reported in Table 2. Generally, changes in ewe and goat milk composition occur by seasons, because the fat, protein, solids, and mineral contents generally increase toward the end of the lactation, whereas lactose content can decrease slightly (Carta et al., 1995; Macciotta et al., 2005; Park et al., 2007). The level of SCC varies during lactation and it could be particularly high at the end of lactation, even in nonmastitic milk (Park et al., 2007; Pirisi et al., 2007). The trend of the parameters measured was consistent with data reported in the literature for only goat milk samples.

For the ewe milk samples analyzed, significant differences were found for $\mathrm{pH}, \mathrm{SCC}$, fat, and protein for all samples depending on the lactation phase, even though the trend was not expected.

\section{Antibiotic Evaluation Trials}

A very low percentage of false-positive results was obtained. Out of 7,704 negative control samples tested ( $\mathrm{n}=3,816$ of ewe milk and $\mathrm{n}=3,888$ of goat milk), $7(0.18 \%)$ and $1(0.02 \%)$ false-positive results were obtained for ewe and goat milks, respectively. Falsepositive outcomes constitute an important problem be-

Table 2. Chemical characteristics, SPC, and SCC of the milk samples (mean \pm SD) used for the tests in early, middle, and final stages of lactation

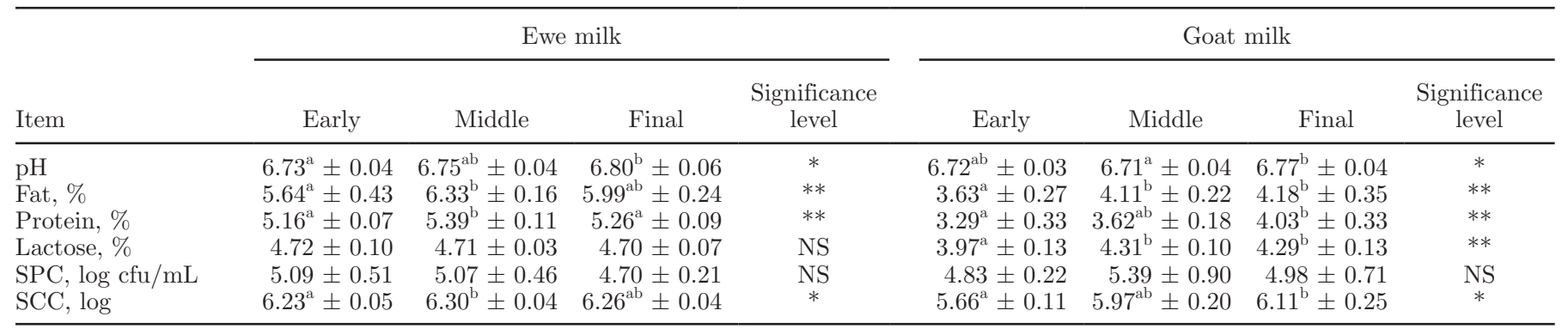

\footnotetext{
${ }^{\mathrm{a}, \mathrm{b}} \mathrm{Means}$ in the same row with different superscripts differ significantly.

${ }^{*} P<0.05 ;{ }^{* *} P<0.01$.
} 


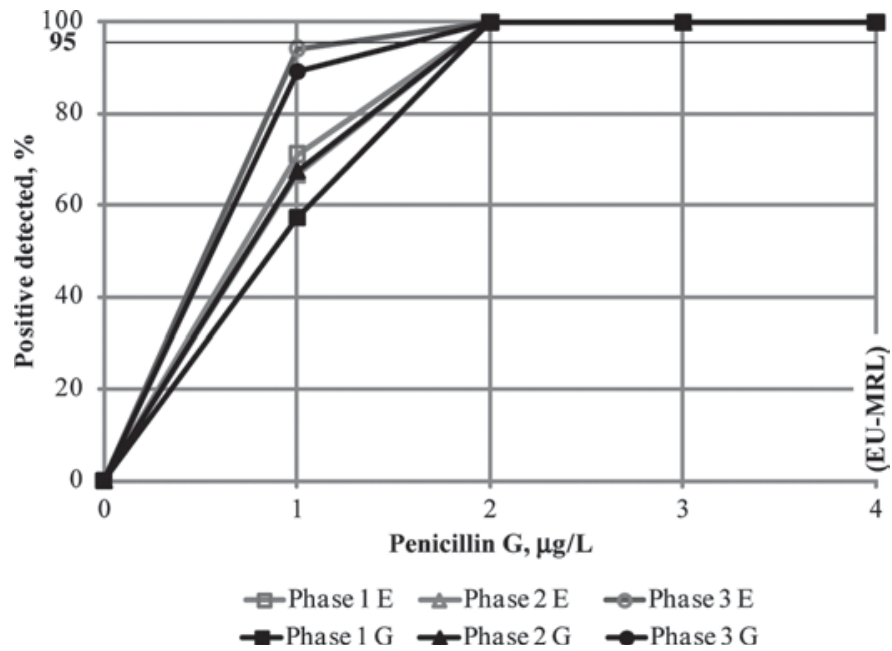

Figure 2. Estimation of penicillin G detection limit by a doseresponse curve in raw ewe (E) and goat $(\mathrm{G})$ milk, during the whole lactation period (phases 1, 2, and 3). EU-MRL = European Union maximum residue limit.

cause they result in discarded milk and hence economic losses (Andrew et al., 1997).

Penicillin G. During the whole lactation period, the Delvotest Accelerator was able to detect all ewe and goat milk samples containing 2,3 , or $4 \mu \mathrm{g} / \mathrm{L}$ of penicillin $\mathrm{G}$, and lower than $95 \%$ of milk samples spiked at $1 \mu \mathrm{g} / \mathrm{L}$ (Figure 2). Therefore, for this antibiotic, the detection limit for both milks fell between 1 and $2 \mu \mathrm{g} / \mathrm{L}$, lower than the EU-MRL $(4 \mu \mathrm{g} / \mathrm{L})$. For ewe milk, a lower detection limit $(1 \mu \mathrm{g} / \mathrm{L})$ was obtained by Althaus et al. (2003) using the Delvotest SP NT test by

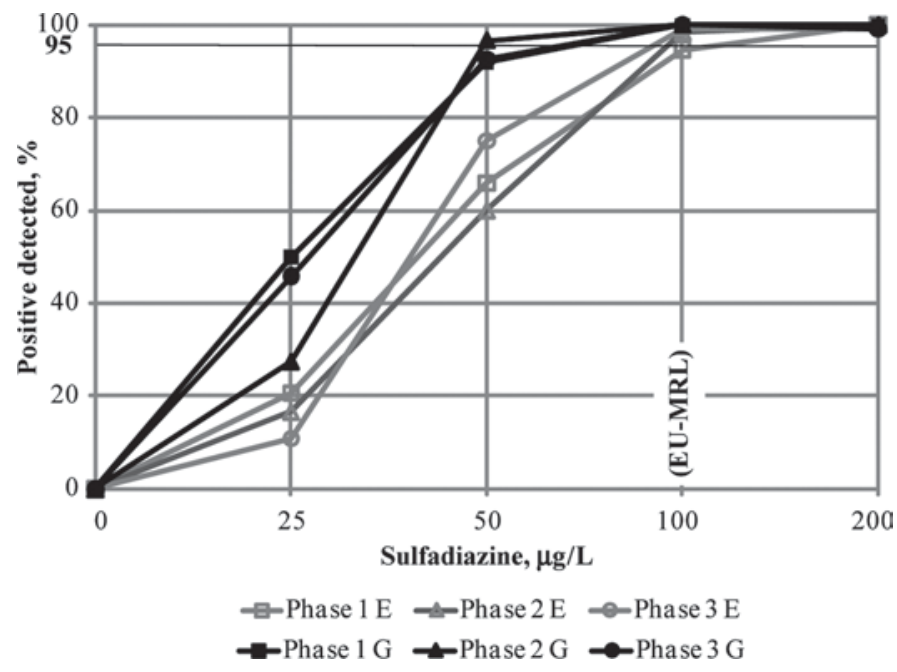

Figure 3. Estimation of sulfadiazine detection limit by a doseresponse curve in raw ewe $(\mathrm{E})$ and goat $(\mathrm{G})$ milk, during the whole lactation period (phases 1, 2, and 3). EU-MRL = European Union maximum residue limit. means of photometric measurements, whereas, for goat milk, Escobar (1999) obtained a range of detection limit between 3.1 and $5 \mu \mathrm{g} / \mathrm{L}$ using different antibiotic residue test kits. Therefore, the Delvotest Accelerator can be considered more effective than previously described methods for detecting penicillin $\mathrm{G}$ residues, especially when milk samples from different species have to be checked.

Sulfadiazine. The detection limit of sulfadiazine reported in the literature (Althaus et al., 2003) for ewe milk is $88 \mu \mathrm{g} / \mathrm{L}$. In this study, the detection limit during the entire lactation period was in the range 50 to $100 \mu \mathrm{g} / \mathrm{L}$ for both ewe and goat milk samples (Figure $3)$.

For milk samples spiked with antibiotic concentrations lower than the EU-MRL, better results were obtained for goat milk during the whole lactation period. The best result was obtained for goat milk samples analyzed during the middle lactation phase, because the system was able to detect the highest percentage (97\%) of positive samples at the lowest detectable concentration (50 $\mu \mathrm{g} / \mathrm{L})$.

Tetracycline. The Delvotest Accelerator detected $95 \%$ of positive samples only at the highest tested concentration $(400 \mu \mathrm{g} / \mathrm{L}), 4$ times the EU-MRL value (100 $\mu \mathrm{g} / \mathrm{L}$ ), for spiked ewe milk samples analyzed during the final lactation period. Very different results were obtained during the 3 lactation phases: at the same drug concentration $(400 \mu \mathrm{g} / \mathrm{L}), 39$ and $83 \%$ of positive samples were detected in phases 1 and 2 , respectively. Therefore, a detection limit $(400 \mu \mathrm{g} / \mathrm{L})$ for ewe milk was determined only during phase 3 (Figure 4).

The tetracycline detection limit for goat milk was in the range 200 to $400 \mu \mathrm{g} / \mathrm{L}$. However, $99 \%$ of goat milk samples spiked with $400 \mu \mathrm{g} / \mathrm{L}$ of the drug were already detected during the middle phase of lactation, and $96 \%$ during the final phase (Figure 4). Moreover, the percentages of positive goat milk samples detected were almost always higher than those of ewe milk.

Althaus et al. (2003) reported a tetracycline detection limit of $590 \mu \mathrm{g} / \mathrm{L}$ for ewe milk with the Delvotest SP NT by means of photometric measurements, much higher than the EU-MRL, and they suggested that it could be due to the low sensitivity of $G$. stearothermophilus var. calidolactis for tetracyclines. On the contrary, we supposed that ewe milk could interfere with the activity of tetracycline and for this reason we performed a trial replacing milk with water. In this way, we obtained $100 \%$ of positive results for the lower tested concentration (50 $\mu \mathrm{g} / \mathrm{L}$; data not shown). Therefore, it would seem that G. stearothermophilus var. calidolactis is quite sensitive to tetracycline, and the poor detection ability could be due to an interaction between ewe milk and this antibiotic. 


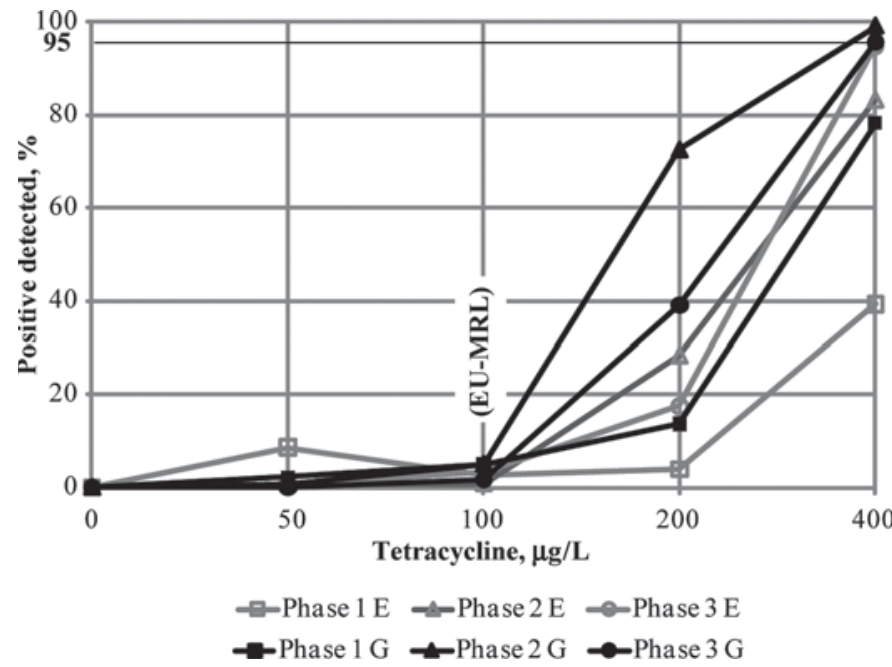

Figure 4. Estimation of tetracycline detection limit by a doseresponse curve in raw ewe $(\mathrm{E})$ and goat $(\mathrm{G})$ milk, during the whole lactation period (phases 1, 2, and 3). EU-MRL = European Union maximum residue limit.

Gentamicin. At the highest tested concentration of gentamicin $(200 \mu \mathrm{g} / \mathrm{L})$, greater than the EU-MRL (100 $\mu \mathrm{g} / \mathrm{L}$ ), the Delvotest Accelerator was able to detect 3, 26 , and $27 \%$ of positive ewe milk samples in phases 1,2 , and 3 , respectively (Figure 5 ), so it was not possible to determine the detection limit. At a concentration equal

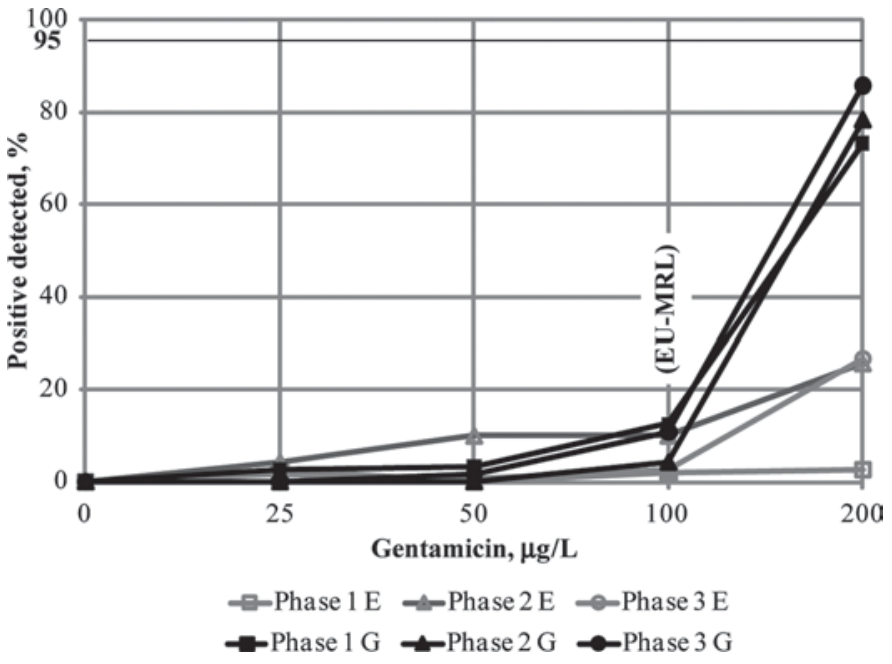

Figure 5. Gentamicin dose-response curve in raw ewe (E) and goat (G) milk, during the whole lactation period (phases 1, 2, and 3). EU$\mathrm{MRL}=$ European Union maximum residue limit.

to the EU-MRL, the percentage of positive results ranged between 2 and 10\%. As seen for tetracycline, the failure of the tests does not seem to be due to a low sensitivity of $G$. stearothermophilus to aminoglycosides as reported in the literature (Althaus et al., 2003; Stead et al., 2004), because $100 \%$ of positive samples were

Table 3. Association of lactation phase with the detection ability of Delvotest Accelerator in early, middle, and final stages of lactation



${ }^{1} \chi^{2}$ test; - = statistical test not applicable.

${ }^{2}$ Fisher's exact test.

${ }^{*} P<0.05 ;{ }^{* *} P<0.01$. 
Table 4. Association of type of milk (ewe/goat) with the detection ability of Delvotest Accelerator

\begin{tabular}{lrcc}
\hline & \multicolumn{3}{c}{ Spiked milk samples detected, $\%$} \\
\cline { 2 - 4 } Antibiotic, & $\begin{array}{c}\text { Ewe } \\
\text { milk }\end{array}$ & $\begin{array}{c}\text { Goat } \\
\text { milk }\end{array}$ & $\begin{array}{c}\text { Significance } \\
\text { level }\end{array}$ \\
\hline $\mathrm{g} / \mathrm{L}$ & & & \\
\hline Penicillin $\mathrm{G}$ & 76.43 & 69.29 & $*$ \\
1 & 100.00 & 100.00 & $-{ }^{-}$ \\
2 & 100.00 & 100.00 & - \\
3 & 99.76 & 100.00 & $\mathrm{NS}$ \\
4 & & & \\
Sulfadiazine & 16.41 & 41.79 & $* *$ \\
25 & 66.92 & 93.59 & $* *$ \\
50 & 97.18 & 100.00 & $* *$ \\
100 & 99.74 & 100.00 & $\mathrm{NS}$ \\
200 & & & \\
Tetracycline & 3.85 & 1.19 & $*$ \\
50 & 2.31 & 4.05 & NS \\
100 & 15.64 & 35.00 & $* *$ \\
200 & 70.00 & 89.29 & $* *$ \\
400 & & & \\
Gentamicin & 2.82 & 1.03 & NS \\
25 & 3.33 & 1.79 & NS \\
50 & 4.62 & 9.49 & $* *$ \\
100 & 17.18 & 78.72 & $* *$ \\
200 & & &
\end{tabular}

${ }^{1}$ Statistical test not applicable.

${ }^{*} P<0.05 ;{ }^{*} P<0.01$.

detected for all the tested concentrations (data not shown) using water instead of milk.

The Delvotest Accelerator was not able to determine the range of detection limit for goat milk even though much better results were obtained than for ewe milk. In fact, the instrument was able to detect 73,78 , and $86 \%$ of positive goat milk samples containing $200 \mu \mathrm{g} / \mathrm{L}$ (twice the EU-MRL concentration) of gentamicin during phases 1, 2, and 3, respectively (Figure 5 ). At the same concentration, only 3,26 , and $27 \%$ of spiked ewe milk samples were detected.

\section{Statistical Analysis}

Lactation phase affected the ability of the Delvotest Accelerator to determine the detection limit only for samples spiked with $400 \mu \mathrm{g} / \mathrm{L}$ of tetracycline, for either ewe or goat milk (Table 3). Significant effects of lactation phase were highlighted in other cases in which, however, the detection limit was not determined. Therefore, overall, lactation phase did not seem to be a crucial factor for the system's detection ability.

Species affected the ability of the Delvotest Accelerator to detect gentamicin $(P<0.01)$, tetracycline $(P<$ 0.05 and $P<0.01)$, and sulfadiazine $(P<0.01)$ in spiked milk samples (Table 4). For penicillin G (the antibiotic most easily detected in both ewe and goat milk), an association $(P<0.05)$ of species with detection ability was found only for milk samples spiked with the low- est antibiotic concentration tested (1/4 EU-MRL). In general, higher detection ability was observed for goat milk samples compared with ewe milk samples.

No correlation between the percentage of spiked milk samples detected and the variations of milk parameters was found except for gentamicin. For this antibiotic, a low negative correlation between percentage of positive milk samples detected and fat $(\mathrm{r}=-0.22 ; P<0.05)$, protein $(\mathrm{r}=-0.26 ; P<0.05)$, and lactose $(\mathrm{r}=-0.24$; $P<0.05)$ contents was found, indicating that higher values of these milk components might reduce the ability of the system to detect gentamicin residues.

\section{CONCLUSIONS}

The Delvotest Accelerator proved to be an easy-to-use and quick system, for both ewe and goat milk, showing a good ability to detect penicillin $\mathrm{G}$ and sulfadiazine. Moreover, very low percentages of false-positive results were obtained. This ia an important outcome, because false-positive results would erroneously lead to the removal of milk intended for feeding or dairy food production with consequent economic loss. For tetracycline, it was possible to determine the range of detection limit only during the final lactation phase for ewe milk and during the middle and the final phases for goat milk, but at a concentration 4 times the EU-MRL. For gentamicin, the tested concentrations were not sufficient to determine the range of detection limit in any lactation phase, for either ewe or goat milk samples. Statistically analyzing the results separately for ewe and goat samples, the ability of Delvotest Accelerator to determine the detection limit did not seem to be related to lactation phase or to the related milk variations in $\mathrm{pH}$, fat, protein, lactose, SCC, and SPC. Detecting spiked milk samples would seem less difficult for goat milk samples than for ewe milk samples. The hypothesis of a low sensitivity of $G$. stearothermophilus to tetracycline and gentamicin did not seem to be confirmed by the results found in this study. Difficulty identifying the detection limits could be due to a food matrix-antibiotic interaction (i.e., $\mathrm{Ca}^{2+} / \mathrm{Mg}^{2+}$-mediated binding action, inactivation, reduction of diffusion in the agar medium) or to the system of analysis (Lunestad and Goksøyr, 1990; Stead et al., 2004). Further studies should be carried out to understand what factors in milk composition prevent the Delvotest Accelerator from detecting some drugs at concentrations near the EU-MRL and to improve the detection ability of the system.

\section{ACKNOWLEDGMENTS}

The authors thank Giuseppe Pizzocri from DSM Food Specialties S.p.A. (Segrate, MI, Italy) for his sup- 
port, and the following people from AGRIS Sardegna Research Agency (Olmedo, SS, Italy) for their valuable assistance in conducting this study: Pietro Moledda for chemical analyses, Salvatore Sanna for microbiological analyses, and Margherita Addis and Stefania Sechi for their support in statistical analysis. This research was partially funded by DSM Food Specialties, Dairy Ingredients (Delft, the Netherlands).

\section{REFERENCES}

Althaus, R. L., A. Torres, A. Montero, S. Balasch, and M. P. Molina. 2003. Detection limits of antimicrobials in ewe milk by Delvotest photometric measurements. J. Dairy Sci. 86:457-463.

Andrew, S. M. 2000. Effect of fat and protein content of milk from individual cows on the specificity rates of antibiotic residue screening tests. J. Dairy Sci. 83:2992-2997.

Andrew, S. M., R. A. Frobish, M. J. Paape, and L. J. Maturin. 1997. Evaluation of selected antibiotic residue screening tests for milk from individual cows and examination of factors that affect the probability of false-positive outcomes. J. Dairy Sci. 80:30503057.

Beltran, M. C., R. L. Althaus, I. Berruga, A. Molina, and M. P. Molina. 2007. Microbiological methods for detection of inhibitors in goat milk. Pages 147-149 in Acts of the 5th International Symposium on the Challenge to Sheep and Goats Milk Sectors, Alghero, Italy.

Carta, A., S. R. Sanna, and S. Casu. 1995. Estimating lactation curves and seasonal effects for milk, fat and protein in Sarda dairy sheep with a test day model. Livest. Prod. Sci. 44:37-44.

Codex Alimentarius Commission. 2009. Maximum residue limits for veterinary drugs in foods updated as at the 32nd session of the Codex Alimentarius Commission (July 2009).

Contreras, A., M. J. Paape, A. L. Di Carlo, R. H. Miller, and P. Rainard. 1997. Evaluation of selected antibiotic residue screening tests for milk from individual goats. J. Dairy Sci. 80:1113-1118.

Demoly, P., and A. Romano. 2005. Update on beta-lactam allergy diagnosis. Curr. Allergy Asthma Rep. 5:9-14.

Escobar, E. N. 1999. Use of antibiotic residue test kits for goat milk. Pages 115-118 in Proc. 14th Ann. Goat Field Day, Langston Univ. Langston, Ok.

European Union. 1990. (EEC) No 2377/90 of 26 June 1990 laying down a Community procedure for the establishment of maximum residue limits of veterinary medicinal products in foodstuffs of animal origin. Off. J. L 224:1-8.

European Union. 2010. Regulation (EU) No 37/2010 of 22 December 2009 on pharmacologically active substances and their classification regarding maximum residue limits in foodstuffs of animal origin. Off. J. L 15:1-72.

European Union. 2009. Regulation (EC) No 470/2009 of 6 May 2009 laying down Community procedures for the establishment of residue limits of pharmacologically active substances in foodstuffs of animal origin, repealing Council Regulation (EEC) No 2377/90 and amending Directive 2001/82/EC of the European Parliament and of the Council and Regulation (EC) No 726/2004 of the European Parliament and of the Council. Off. J. L 152:11-22.
International Dairy Federation. 1991. Milk and milks products. Enumeration of microorganisms-Colony count at $30^{\circ} \mathrm{C}$. FIL-IDF No. 100 B. Int. Dairy Fed., Brussels, Belgium.

International Dairy Federation. 2003. Milk and milk products. Guidelines for a standardized description of microbial inhibitor tests. FIL-IDF Standard No. 183. Int. Dairy Fed., Brussels, Belgium.

Lunestad, B. T., and J. Goksøyr. 1990. Reduction in the antibacterial effect of oxytetracycline in sea water by complex formation with magnesium and calcium. Dis. Aquat. Organ. 9:67-72.

Macciotta, N. P. P., P. Fresi, G. Usai, and A. Cappio-Borlino. 2005. Lactation curves of Sarda breed goats estimated with test day models. J. Dairy Res. 72:470-475.

Molina, M. P., R. L. Althaus, S. Balasch, A. Torres, C. Peris, and N. Fernandez. 2003a. Evaluation of screening test for detection of antimicrobial residues in ewe milk. J. Dairy Sci. 86:1947-1952.

Molina, M. P., R. L. Althaus, R. L. Molina, A. Torres, and N. Fernandez. 2003b. Antimicrobial agent detection in ewe milk by the microbial inhibitor test (Brilliant Black Reduction Test - BRTAiM $\left.^{\circledR}\right)$. Int. Dairy J. 13:821-826.

Montero, A., R. L. Althaus, A. Molina, I. Berruga, and M. P. Molina. 2005. Detection of antimicrobial agents by a specific microbiological method (Eclipse $\left.100^{\circledR}\right)$ for ewe milk. Small Rumin. Res. $57: 229-237$.

Park, Y. W., M. Juàrez, M. Ramos, and G. F. W. Haenlein. 2007. Physico-chemical characteristics of goat and sheep milk. Small Rumin. Res. 68:88-113.

Perreten, V., and M. Teuber. 1995. Antibiotic resistant bacteria in fermented dairy products. A new challenge for raw milk cheeses? Proc. Symp. Residues of Antimicrobial Drugs and other Inhibitors in Milk, Kiel, Germany. International Dairy Federation, Brussels, Belgium.

Pirisi, A., A. Lauret, and J. P. Dubeuf. 2007. Basic and incentive payments for goat and sheep milk in relation to quality. Small Rumin. Res. 68:167-178.

Sierra, D., A. Contreras, A. Sánchez, C. Luengo, J. C. Corrales, C. T. Morales, C. de la Fe, I. Guirao, and C. Gonzalo. 2009b. Short communication: Detection limits of non- $\beta$-lactam antibiotics in goat's milk by microbiological residues screening tests. J. Dairy Sci. 92:4200-4206.

Sierra, D., A. Sánchez, A. Contreras, C. Luengo, J. C. Corrales, C. T Morales, C. de la Fe, I. Guirao, and C. Gonzalo. 2009a. Detection limits of four antimicrobial residue screening tests for $\beta$-lactams in goat's milk. J. Dairy Sci. 92:3585-3591.

Sierra, D., A. Sánchez, C. Luengo, F. San Eustaquio, B. Agüera, J. C. Corrales, C. de la Fe, C. T. Morales, and A. Contreras. 2007. Evaluation of antibiotic residue screening test for beta-lactamic detection in goat's milk. Pages 190-191 in Acts of the 5th International Symposium on the Challenge to Sheep and Goats Milk Sectors Alghero, Italy.

Stead, S., M. Sharman, J. A. Tarbin, E. Gibson, S. Richmond, J. Stark, and E. Geijp. 2004. Meeting maximum residue limits: an improved screening technique for the rapid detection of antimicrobial residues in animal food products. Food Addit. Contam. $21: 216-221$

Wang, S., H. Y. Zhang, L. Wang, Z. J. Duan, and I. Kennedy. 2006. Analysis of sulphonamide residues in edible animal products: A review. Food Addit. Contam. 23:362-384.

Yamaki, M., M. I. Berruga, R. L. Althaus, M. P. Molina, and A. Molina. 2004. Occurrence of antibiotic residues in milk from Manchega ewe dairy farms. J. Dairy Sci. 87:3132-3137. 